UDC 332

\title{
THE IMPLEMENTATION OF ONE VILLAGE ORGANIZATION OWNED ENTERPRISE IN SAWAHAN SUB-DISTRICT
}

\author{
Zuhrufia Dina*, Supriyono Bambang, Haryono Bambang Santoso \\ Master's Program in Administrative Science, Faculty of Administrative Science, \\ University of Brawijaya, Indonesia \\ *E-mail: dinazuhrufia@gmail.com
}

\begin{abstract}
Development was an effort conducted to head better directions at all of aspects. Priority agenda of development contained some efforts to realize development equity through village development. Village development was an effort to achieve an independent village. One of the places to get a facility in the effort of realizing independent village is Village Organization Owned Enterprise or BUMDes. Nganjuk district was one of the regions that still needed to improve and develop the activity of BUMDes especially in Sawahan sub-district. One of the programs run by Nganjuk District government was the movement to achieve one village one BUMDes to encourage the creation of 9 BUMdeses in 9 villages of Sawahan sub-district. This program was backgrounded by a big potential owned by Sawahan sub-district to be developed so that becomes an economic pillar for villagers.
\end{abstract}

\section{KEY WORDS}

Implementation, BUMDes, village, independent village.

Development priority contains some efforts to realize development equity. The inequity of development will bring an inequality and gap among the regions. Policy direction to achieve development equity is included in nawacita (nine goals) 3 "Developing Indonesia from the rural area by strengthening regions and villages in the unitary state framework". One of the agendas of development in realizing development equity among the region is through village development.

According to Yuwono (2001), a village is a region having legal unity as a residence in which the community has a power to establish a government. During the period of 20152019 , village development is being intended to a village and community strengthening, as well as the development of the center of growth in the rural area to encourage sustainable rural area improvement having social, economics, and ecological endurance as well as promoting a village-city relationship (Bappenas, 2015). Realizing sustainable social, economics, and ecological endurance is a form of an independent village.

One of the places where we can get a facility to realize an independent village is Village Organization Owned Enterprise or BUMDes. According to Law Number 6 Year 2014 on Village, BUMDes is a business entity whose the entire or partial capital owned by Village through direct attachment coming from Village property separated to manage asset, service fee and other businesses for villagers' welfare. The effort carried out by Nganjuk Local Government in activating BUMDes is the movement to realize one village one BUMDes. The movement to realize one village one BUMDes is based on the Nganjuk Regent Regulation Number 13 Year 2016 on Establishment, Institutional Revitalization and Governance, as well as the dissolution of Village Organization Enterprise and Joint Village Organization Owned Enterprise. This movement expects BUMDes in Sawahan sub-district will be more active and becomes a facility to be an independent village.

\section{METHODS OF RESEARCH}

This was qualitative descriptive research since oriented to the naturalistic and scientific symptoms. Qualitative research was research that intends to understand the phenomenon on what experienced by the research subject by describing words and language, in the scientific and special context by benefiting various scientific methods (Moleong, 2005). The focuses of their research were: 1 . The implementation of one village on BUMDes program 2. Supporting and inhibiting factors of one village one BUMDes program. 
The location was in 9 villages in Sawahan sub-district, i.e. Ngliman village, Sawahan village, Bareng village, Sidorejo village, Margopatut village, Kebonagung village, Duren village and Bendolo village. The source of data in qualitative research was among other informant, circumstances, location, and document (photo, document, archives, journal, and report). The instrument used was the researchers themselves, interview and supporting kits (recorder and camera). The data was analyzed using Creswell's (2012) data analysis with the following stage: (1) managing and preparing data to be analyzed; (2) reading all data; (3) coding data; (4) describing coding result; (5) re-describing; (6) data interpretation.

\section{RESULTS AND DISCUSSION}

The Implementation of One Village one BUMDes. In accordance with Thomas B. Smith's policy implementation, there are four variables that influence each other in the process of policy implementation (Tachjan, 2006).

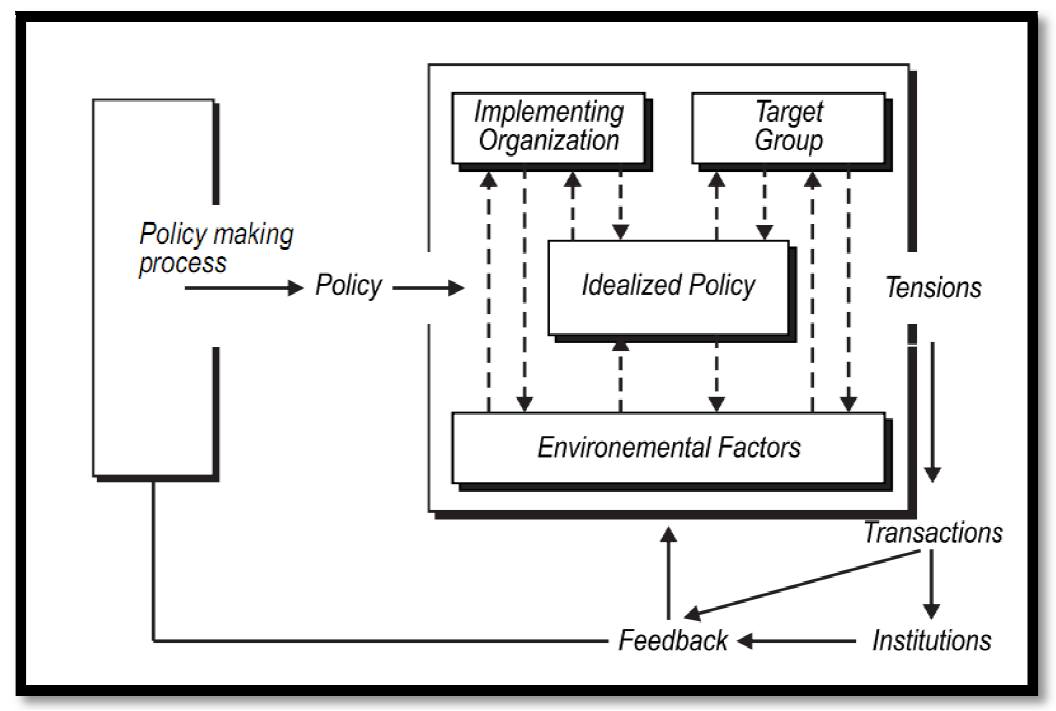

Figure 1 - Smith's Policy implementation Model Source: Tachjan, Public Policy Implementation (2006)

According to that implementation model, program implementation of one village one BUMDes in realizing independent village in Nganjuk district is as follows:

Idealized Policy. An idealized policy is an interaction pattern idealized by drafting team in terms of encouraging target group to perform that policy. This movement of One Village one BUMDes is regulated in Nganjuk Regent Regulation Number 13 Year 2016 on Establishment, Institutional Revitalization And Governance As well As the dissolution of Village Organization Owned Enterprise and Joint Village Organization Owned Enterprise. In its implementation, it is compiled a circular letter Number 140/621/411.304/2016 on Establishment Movement, Institutional Revitalization and BUMDes governance and Joint BUMDes of 2016 as a technical guideline of the implementation of realizing One Village one BUMDes. In terms of this matter, Village and Community Empowerment Service as the implementing organization conduct a socialization to the Village Government in Sawahan Sub-district concerning BUMDes establishment and its management. In addition, the government village in Sawahan Sub-district is also provided by Management skill. This training is also an action to idealize policy. An interaction happened between Community and Village Empowerment Service and the target group is a process of information provision so that the policy can be accepted.

Target Group. A target group is a subject intended in the policy implementation. The success of policy implementation is assessed by the size of target group's responsiveness in accepting that policy. Analysis related to the target group responsiveness is concluded that target group has accepted policy delivered by the implementing organization. In this term, the village government in Sawahan Sub-district can establish BUMDes in relation to the target listed in its technical guideline. BUMDes in 9 villages of Sawahan Sub-district is as follows: 
Eurasia: Economics \& Business, 7(13), July 2018

DOI https://doi.org/10.18551/econeurasia.2018-07

Table 1 - Village Organization Owned Enterprise in Sawahan Sub-district

\begin{tabular}{|l|l|l|}
\hline Village & BUMDes Name & Business Activity \\
\hline Ngliman & Dewa Daru & Saving and Loan, Tourism Village, Kiosk rental \\
\hline Sawahan & Sawahan Makmur & Saving and Loan, Rental, Tourism Village \\
\hline Bareng & Bareng Lestari & Saving and Loan, Livestock, Rental \\
\hline Sidorejo & Srikandi & Saving and Loan \\
\hline Margopatut & Margo Mulyo & Saving and Loan, Tourism Village \\
\hline Siwalan & Argo Wilis & Saving and Loan \\
\hline Kebonagung & Bumi Agung & Saving and Loan, Tourism Village \\
\hline Duren & Duren Makmur & Saving and Loan \\
\hline Bendolo & Bendolo & Saving and Loan \\
\hline
\end{tabular}

Source: Articles of association and bylaws (AD/ART) of BUMDes in Sawahan Sub-district.

Implementing Organization. Implementing organizations are an implementing policy of both organization and person, Characteristic and story. A bureaucratic structure can influence the success of policy implementation. In the implementation of one Village One BUMDes, Community and Village Empowerment Service have fit characteristic and criteria of a bureaucratic structure so that able to support BUMDes development effort. In addition, resources also influence the success of policy implementation. Any resources of Community and Village Empowerment apparatus by 29 people have a background in education, rank and classification like the following table:

Table 2 - Apparatus Resource

\begin{tabular}{|l|l|l|l|l|}
\hline No & Type of Formal Education & M & F & Total (M+F) \\
\hline 1 & Elementary School & 0 & 0 & 0 \\
\hline 2 & Junior High School & 0 & 0 & 0 \\
\hline 3 & Senior/Vocational High School & 5 & 2 & 7 \\
\hline 4 & D3/D4 (Associate Degree) & 0 & 2 & 2 \\
\hline 5 & Bachelor's Degree & 6 & 7 & 13 \\
\hline 6 & Master's Degree TOTAL & 5 & 2 & 7 \\
\hline & 16 & 13 & 29 \\
\hline
\end{tabular}

Source: Strategic Planning of Community and Village Empowerment of 2014.

The ability of Community and Village Empowerment Service's apparatus in Nganjuk Sub-district is quantitatively not adequate yet with the workload in each subject so that it frequently happens work overload that at the end causes less optimum performance. This causes the implementation of one village one BUMDes program less optimum. Therefore, village facilitator comes to guide a village and help to implement the program of one village one BUMDes. Village facilitator divided into three levels, i.e. district area, sub-district and village area executed its duty with coordination system. This relationship pattern is called fragmentation, that is responsibility spread. In the implementation of one village on BUMDes program, the existence of village facilitator is one of the factors that support the success of the implementation.

Environmental Factors. In a policy implementation, economic environment, social and political factor has an influence on the implementation success. The way to assess performance's success or failure is to what extent external environment encourages the success of public policy.

Table 3 - Profile Value of 9 Villages in Sawahan Sub-district

\begin{tabular}{|c|c|c|c|c|c|c|}
\hline Village & $\begin{array}{l}\text { Community } \\
\text { Economy }\end{array}$ & $\begin{array}{c}\text { Society } \\
\text { Education }\end{array}$ & $\begin{array}{l}\text { Community } \\
\text { Health }\end{array}$ & $\begin{array}{l}\text { Safety } \\
\text { and } \\
\text { Order }\end{array}$ & $\begin{array}{l}\text { Community } \\
\text { Political } \\
\text { Sovereignty }\end{array}$ & $\begin{array}{c}\text { Community } \\
\text { participation in a } \\
\text { development }\end{array}$ \\
\hline Ngliman & 0.53 & 0.64 & 0.76 & 1.00 & 0.85 & 0.78 \\
\hline Sawahan & 0.61 & 0.70 & 0.79 & 1.00 & 0.76 & 1.00 \\
\hline Bareng & 0.56 & 0.70 & 0.68 & 0.95 & 0.80 & 0.89 \\
\hline Sidorejo & 0.49 & 0.70 & 0.80 & 1.00 & 0.89 & 0.78 \\
\hline Margopatut & 0.62 & 0.65 & 0.78 & 1.00 & 0.78 & 0.89 \\
\hline Siwalan & 0.68 & 0.75 & 0.71 & 1.00 & 0.74 & 0.78 \\
\hline Kebonagung & 0.54 & 0.71 & 0.74 & 1.00 & 0.90 & 0.89 \\
\hline Duren & 0.94 & 0.96 & 0.88 & 1.00 & 0.76 & 0.89 \\
\hline Bendolo & 0.50 & 0.60 & 0.84 & 1.00 & 0.76 & 0.89 \\
\hline
\end{tabular}

Source: Information System of Village Profile in 2017. 
The essence of BUMDes establishment was to increase community's economy and welfare. The target group of the implementation of One Village One BUMDes program was village government, but the purpose expected to be achieved by the existence of BUMDes was absolutely oriented to increase economy and community's welfare. The establishment, the development and the activities of BUMDes were expected able to give big impact especially in the field of economics to the community. Community economy's condition in Sawahan sub-district still categorized middle-low became an implementation supporting of a movement to realize one Village One BUMDes. BUMDes was expected able to become a facility to increase community's economy and welfare.

Village social condition in Sawahan Sub-district was truly conducive. Community in Sawahan sub-district has an important role in honoring togetherness. This became one of the factors supporting the success of the implementation of One Village one BUMDes program. Community's political participation in Sawahan Sub-district is extremely high. That high political appreciation shows that the community in Sawahan sub-district has good assessment and appreciation to the government and their policy which change it into a support in the implementation of One Village One BUMdes.

\section{CONCLUSION}

An idealized policy is how that policy is communicated to the target group. Socialization related to the technical guideline of BUMDes establishment is an effort to idealize policy. In addition, management training to the village government in Sawahan Sub-district is also an effort to communicate policy.

Target Group is a subject targeted in the policy implementation. The success of policy implementation is assessed from the size of responsiveness of the target group in accepting that policy. Responsiveness of village government is extremely high. This is shown by the establishment of 9 BUMDeses in Sawahan Sub-district.

Implementing Organization is both institution and person. Characteristic and Bureaucratic Structure can influence the success of policy implementation. In its implementation Community and Village Empowerment Service has a fir characteristic and bureaucratic structure so that able to support the development effort of BUMDes. In addition, Resources also influence the success of policy implementation. The ability of Community and Village Empowerment Service apparatus of Nganjuk village is quantitatively not adequate enough with the existing workload in each department which frequently causes an overload that at the end will cause not optimum performance. This causes the implementation of one Village one BUMDes program is not maximum yet. Thus, the facilitator comes to accompany village and to help the implementation of one village one BUMDes program.

In a policy implementation, factors of economic environment, socio-economics and politics have an influence on the success of the implementation of community's economic condition. Sawah sub-district still categorized low-middle becomes an implementing supporter of the movement of realizing one Village One BUMDes. Village social condition in Sawahan Sub-district is truly conducive. Community in Sawahan Sub-district has a high role to build togetherness. This supports the success of the implementation of One Village One BUMDes. Community participation in politics is relatively high. The high political appreciation shows that community in Sawahan sub-district has good assessment and appreciation to the government and their policies which change them into support in the implementation of One Village one BUMDes program.

\section{REFERENCES}

1. Creswell, J.W. (2012). Qualitative inquiry and Research Design: Choosing among five approaches $\left(3^{\text {rd }} \mathrm{Ed}\right)$. California: Thousand Oaks.

2. Moleong, L. J. (2007). Metodologi Penelitian kualitatif. Bandung: PT.Remaja Rosdakarya.

3. Tachjan. 2006. Implementasi Kebijakan Publik. Bandung : AIPI

4. Yuwono, T. (2001). Manajemen Otonomi Daerah. Semarang: Pusat Kajian Otonomi Daerah dan Kebijakan Publik (Puskodak). 